\title{
コメ食民族 の食生活誌
}

福 田一 郎

(東京女子大学教授)

\section{はじめに}

現在世界人口の半分 27 億の民族は，コ人食を主として 生活している。アジアの民族の多くは，年間 5 億卜ンの コ久生産に依存して毎日の生活を送っている。人類が農 耕を開始して以来 1 万年の歴史で, 多くの野生植物の中 でイネを特に選んで栽培化にもちこみ，今日の食生活の 基盤をつくったことは深い意味がある。

\section{1.コメ食の利点}

ほかの栽培植物に比べて, コ人食の利点としてあげら れるものに次のよらな点がある。

（1）コメーイネの生産性が高い

コメは水田耕作を主とするが，それによって一定面積 から得られる收檴高はコムギなどの畑作物の 2 倍近く, 最飞効率よい生産性を維持している。

（2）コメは美味く，しかも栄養価が高い

コメの主成分はデンプン質であるが，そのアミラーゼ とアミロペクチンの微妙な含有のバランスによっておい しさがつくられている，その1キログラム当たりのカロ リーはコメ $3,560 \mathrm{kcal}$, コムギ $3,330 \mathrm{kcal}$, トウモロコ シ $3,500 \mathrm{kcal}$ と人類の必須三大穀物の中で最も高い.

(3) コメは粒食のままで食べられる

コムギ，オオムギなど多くの穀物が粉食の過程を経て 食事に供されるが，コ从は粒食でそのま关劣炊きで食 べることができる、これは他の穀物に比べて料理をする 上で有利な点である。

さて，こうした利点をいかして，アジアの諸民族は具 体的にどのような食生活の形態をとっているであうら か、ここでその実態調査の分析に，照葉樹林文化帯にお けるネパール, 雲南として日本民族の食生活のもとを追 究する試みを展開してみよう。

本稿は第 9 回研究集会の特別講演をまとめたものである.
照葉樹林文化論を提唱したのは中尾佐助, 佐々木高明 教授ら京都学派の人たちで, 日本, 雲南, ヒマラヤを結 ぶ地域に常緑で葉の表面が光っている一ッバキ科, クス ノキ科など一樹林が存在し，その樹林のもとに共通する 文化が存在しているといら説を打ち出した、私はこの文 化論に注目し，この地域に住んでいる民族はコ人食を基 礎としているが，そのコ人食の展開・動態は民族に共通 しているのか，異なっているのかを明らかにするべく研 究計画をたてた、コ人食とそれ秃伴ら食生活の実態は, イネの種類，作付状況，生産状況の把握から，それを用 いての食生活梯式一1 日何回の食事か, 制菜はどらいら ものを用いるかといった点を明らかにする必要があり， 現地を訪れて研究することにした。ここではネパールの 調查開始の1975年来20回, 雲南へは1985年来10回にわた る調査結果をまとめ，そ狆に日本の資料を加えて考察す ることにした。

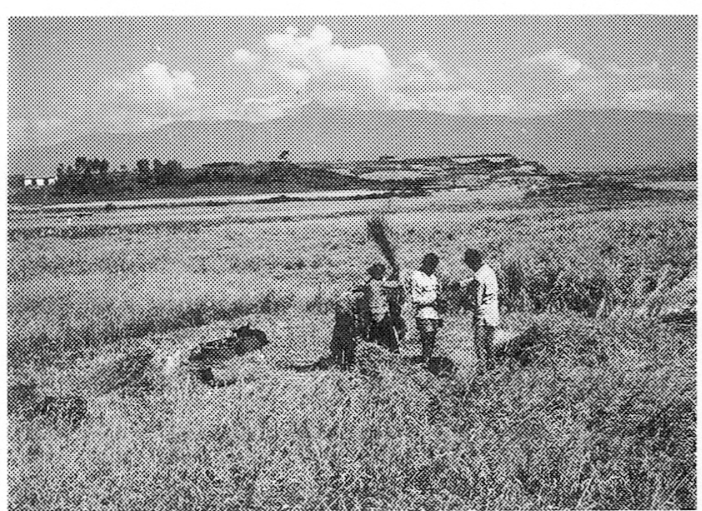

図１ ネパールのカトマンズ盆地でのコメの収穫（高度 1,300 メートル 1991.10)

\section{2 、ネパール諸民族の食生活の実態}

ヒマラヤ山系の一角を占めるネパールの国は, その都 カトマンズが高度 1,300 メトルで, 周辺の山間部に段 々畑が展開している（図1)。コ人食中心で1日 2 回の 
表 1 ネパールで日常使われている香辛料

\begin{tabular}{|c|c|c|}
\hline ネパール名 & (通稱) & （植物科名） \\
\hline Methi & コロ八 & マ处科 \\
\hline Beshar & ウコン & ショウガ科 \\
\hline Jeera & ウマピり & せリ科 \\
\hline Dhaniya & コエンドロ & 七リ科 \\
\hline Jwano & ジワノ & セリ科 \\
\hline Tejpt & インド桂葉 & ゲッケイシュ科 \\
\hline Lahsum & ニンニク & ニリ科 \\
\hline Aduwa & ショウガ & ショウガ科 \\
\hline Till & ゴマ & ゴマ科 \\
\hline Nepali Sunp & イノンド & 七リ科 \\
\hline Timmur & サンショウ & ミカン科 \\
\hline Zimbu & ジンブ & 二リ科 \\
\hline Koma & $\exists マ$ & セリ科 \\
\hline Khursani & トウガラシ & ナス科 \\
\hline
\end{tabular}

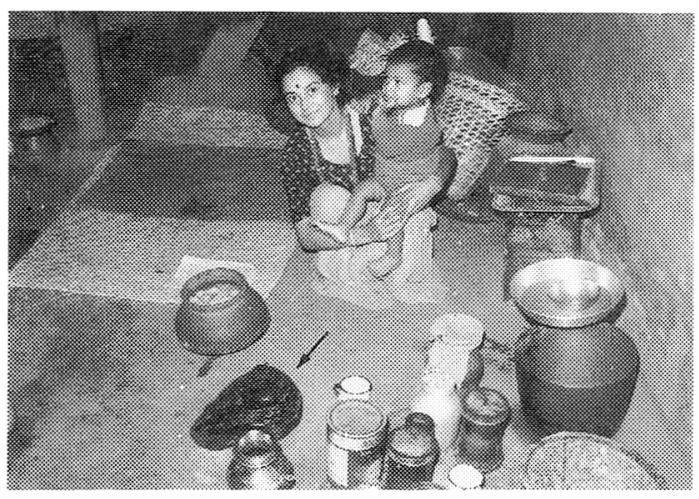

図 2 チェトリー族の若奥さんは子守りをしながら香辛料を石 臼（矢印）でつぶしてカレー料理をつくっている(1983.10)

食事が普通である.

カトマンズの郊外にウォッツウといらチェトリー族の 農村がある.コメ作中心で，1,300人ートルの高地の水 田には, ジャポニカ米の「タイチェン」「マルチ」「ダウ ラ」といった品種を一毛作でつくっている.インディカ 米の「マシノ」を少しつくっているが収量が劣る：この ジャポニカ米を炊いたご飯一ネパール語でダートと呼ば れている一にカレー料理を㡺と夜 2 食つくって食べる. 朝はお茶に炒ったマ人などでつ李导程度ですませてい る.

このカレー料理は「タルカリー」といって野菜中心の カレー入りの惣菜であるが，問題は香辛料の使い方で, ウコン, ウマゼリ, コロ八, カシア桂葉, ショウガ, 二 ンニク，コエンドロ，それに辛いトウガラシというよう に実に豊富に使っている（表1）。使用するそれぞれの 香辛料の分量・配合が微妙な味をかもしだし, 独特の料
理をつくることができる.

実は一日 2 食のカレー料理を昼は若奥さんが，夜は和 ばあちゃんがつくるといったことで味の違うものをつく り，なんと，毎日バートとカレー料理で生活している(図 $2)$. 白米のご飯にカレーといら組合せは, 単純な種類 の素材から複雑な味の料理をつくり出し，実によくでき ていると思われる。カトマンズ盆地のネパールの人たち は, 多くはヒンズー教を信仰し, 牛肉は食べない。した がって, 日常もっぱら野菜中心の料理になるが，カレー 料理はそのよらな制約のなかで, 香辛料をらまく組及合 わせて何種類にも匹敵する食事をつくっている。だから 毎日カレー料理を食べても飽きることがない。

カトマンズのバザールを歩いてみると，たと立店構光 は小さととも，こうした香辛料一スパイスを売る店が独 立して，分銅で量って売っていた。そのスパイスの中で も注目すべきものはトウガラシである、ネパールのトウ ガラシは 2 種 4 品種あって, 高地とい5自然条件を反映 して，それらがうまく栽培されているが，民族によって 使われるトウガラシの品種が異なることも興味深い.

西ネパールの町ポカラから 3 日かけて歩いていくとこ ろにグルン族の村パルチェがある。高度 2 , 200 メートル, もらこの高さではコメはつくれない、ところが，このグ ルン族の人たちもコメ食中心の生活を送っている.どら するのか，実は彼らが居住する場所からわざわざおりて きて $1,500 \sim 1,600$ メトルのところでュィをつくり，上 まで収穫したコメを運んで食べている。この村にしばら く滞在して調査をして, 親しくなった村長さんのパダム トジー・グルンにこんな提言をしてみた。「この村の人 たちが700人ートルも下へ抢りていってコィをつくる. そんな苦労をしないで，この周辺の地でュムギ，才オム ギをつくってパン食にきりかえたらどらでしょらか？ (コムギ，才オムギは耐寒性があって2,000メートルを こえる高地でも十分栽培でさる).」ところが意外な答え がかえってきた、「私は若いとき，8年間イギリス軍に 参加してロンドン郊外で過した，そのとき，毎日パンを 食べていた。しかし，村へ帰ってきて，なんとコょのご 飯の拈いしいことか! 私はこのコメのご飯と鵎肉を入れ た野菜のカレー料理が，この世で最高の料理だと思う.」

このグルン族の人たちも, 一日 2 回（10時頃と夕方 6 時頃) の食事で, やはりコ丸のご飯と, これに野菜を主 としたカレー料理を組み合わせる。ただ彼らはラマ教に 帰衣し，食事についての制限はない。1 週に1，2 回， カレー料理のなかに, 肉一ニワトリ一を入れる. 牛肉や マトンを食べるのは, 祝祭日のときぐらいである.カレー 
料理の内容はカトマンズ盆地に住むチェトリー族と基本 的には似ているが，香辛料の種類は少なく，ショウガ， ニンニクの量が多く, トゥガラシの辛味が強いものを用 いていた.

こらしたネパール諸民族の香辛料の使い方は，その居 住している場所の高度に応じて高度 1,300 メトルのカ トマンズ盆地のチェトリー族, ネワール族は種類が豊富 だけでなく，それより南のインドからの影響が大きく， 2,000 メートル近くのタマン族， $2,000 \sim 3,000$ メトル で生活しているグルン族，シェルパ族と高地になる程子 ベットからの影響を受けているといえる。

インドの香辛料としては夕ミン，コリアンダー，フェ ヌーグリーク，ターメリックといらよらに小さな粒の種 子からなるセリ科 Umbelliferaeの植物が多く、これを 砕いてカレー料理に使らので，平らな面をもつ石臼に棒 状の石塊を用いている。タマン族が用いている石臼は凹 みがあるが、これはショウガやニンニクなどショウガ科, ユリ科の根茎が加ってくるからで，それがシェルパ族に なるとシャクナゲの樹の材で中身をくりぬいて深い凹み をつくった木の四に変わっている．これを砕くための棒 はやはり石を用いている。こうなるとチベット料理の影 響といえる。

ネパールは南の低地のインドと北の高地のチベットに はさまれて，民族の歴史の上でも両者に起源するものと みることができるであろらが，食生活の上で同じコ入食 を基盤にしながら香辛料といった微妙な調味の世界で分 化がみられることは興味深い。そらしたことが台所道具 の石臼, 木臼に違いがでてきていることも面白い.ネパー ルで訪れた台所はどこもきれいに掃除されて㧍り，神が まつられていた。

\section{3 . 中国雲南の夕イ族の食生活の実態}

中国の南，雲南地方の調査はひとし挨が入る。それ は雲南地方にイネの起源を求める説（渡部忠世教授のア ッサム・雲南起源説）があるからである。たしかに雲南 の地には野生イネもあり, イネ以外の野生植物の種類も 豊富で，民族の歴史の上から與味深いところである．現 在は 7,000 年前とはっきり年代の測定ができた長江河口 の菏姆渡遺跡を栽培化への起源とする説が有力である が，コメ食の源流を探ぐる上，また照葉樹林文化帯の中 の日本との関連を調べる上で雲南の地を欠くことはでき ない。

先ず雲南の自然の特徵はほぼネパール, 台湾と同じ緯 度の地に位置しているが, 高度は南の西双版納の地は
$430 \sim 2,000$ メートルと起伏に富久, 気候の上では熱帯 から温帯にわたり，年間の温度差は少なく，1日の温度 差が大きい $\left(8 \sim 11^{\circ} \mathrm{C}\right)$. 年平均雨量はそら多くなく平 均 1,200 ミリで日本より少ない, 土壤は黄壤, 紅壤とい った赤土で粒子が細かく, 酸性度が高い.

昆明からさらに南の西双版納の地で調査をしたが, 次 のことが判明した.

（1）照葉樹林として典型的な樹林チャ（茶）の起源はこ の地である。

(2) コメは伝統的には紫米で年 2 回 ( 2 毛作) つくって いた。

(3) 現在コメ作の主流はハイブリッド米（中国では雑交 米と呼んでいる) である.

このよらなことを背景に，どのよらな食生活がみられ るであろらか。西双版納で主流を占めるタイ族（傣）の 農村を訪礼てみら（図３）。

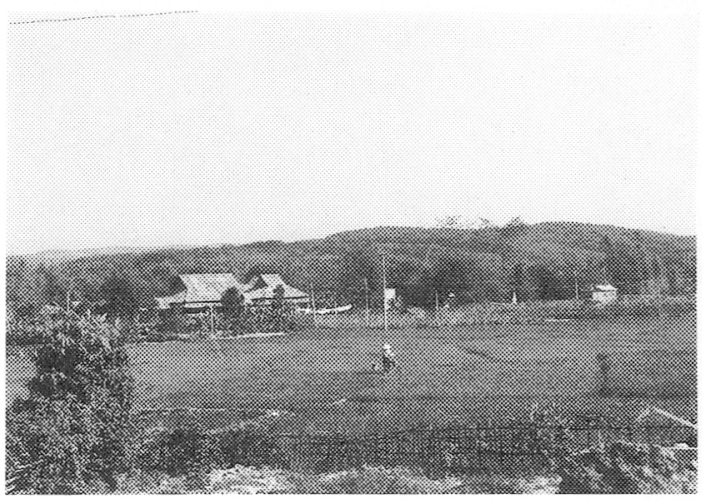

図 3 中国雲南省西双版納 (シーサンパンナ) のコメ作風景 水を運ぶタイ族の娘さんがいく(1994.4)

この地でつくられている紫米であるが，これはアミロ ペクチンを100パーセント含むジャポニカ型のモチ米で 粘りがある、ネパールのグルン族の地でみた黒米, ブー タンでみた赤米とは違って精米の表皮が紫色で（内部は 白い), 炊くと濃い紫色のご飯ができる。それは日本で われわれが祝事のとき食べる赤飯（白いモ千米に小豆を 入れて炊く）上り，もっと濃い紫色をしている。日本の 赤飯の源点はここにあったかと思った。

西双版納のタイ族の食生活は，この紫米のコメ食を主 に，一日 3 回朝㡺晚と惣菜の組合せを变えて食事をする (図 4)，実は1985年以来こうした民族の食生活をみて きたが、この伝統あるコメ食に変化が起こってきた。そ れは中国政府奨励のハイブリッド米の作付が急激に広ま ってきたことが原因となった。10年前は紫米に多収量で 


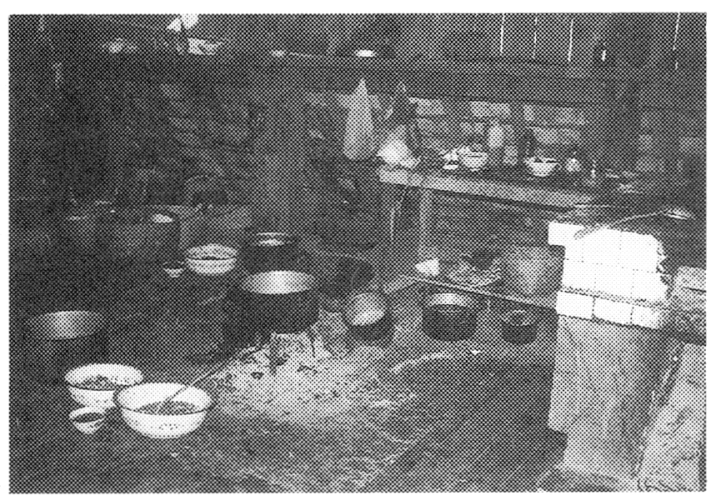

図 4 タイ族入母高床式家屋の台所 (1992.3)
ジャポニカ種の「菠夢矮」(アミロペクチンの量多く, 美味い）が導入され，その両方直自用としてつくって きた。、イブリッド米は生産性は高いがまずく, 政府へ の供出米として用いてきた。

1990年すなわち，5年前はハイブリッド米80パーセン 卜, 自家用20パー七ントは紫米を中心に在来種をつくり, それを食べていた。それが1994年春には95パーセント八 イブリッド米，万パーセント在来米に変わっていた。 そ の原因は, ハイブリッド種の改良が成功しておいしいコ 人ができたことで普及率が高束った点である。もら一つ の要因に考えられるのは, スイカ, トウガラシ,ゴム, チャ, サジンなど経済植物の作付で現金収入が入るよう になって, コくそのもの上りも肉食, 魚食とれに香辛料 がたつぷり買えるよらになったからではないかと考えら れる.昨年春訪れた早タイ族（山地に住むタイ族）の農 家は，「朝と昼は紫米で食事老するが，夜は雑交米で， その方が健康によい」といっていた（夜は寝るだけと なるので，ハイブリッド米のウルチ米の方が消化によい といら意味)

さて,こらしたコメ食を中心に, 宗教的にも何の制約 もなく, 肉 (ブタ・ウシが多い), 魚 (河魚), それに豊 富にある野菜でつくる惣菜の味つけをする香辛料はどん なものを用いているであろらか。

高度500^ートルの水田地帯に住んでいるタイ族は, 生姜, 辣椒, 香菜, 大蒜, 溥花, 草果, 花椒, 茴香, 八 角, 胡椒, 丁香, 胡麻, 香茅草, 苦叶葉とい5よ5に香 辛料は実に豊富である(表 2 )。ネパールの山地民族に 比べると種類も多く, 自家用として家の周用に植えてい るものもあるが，バザール（市場）では個人経営で売っ ている香辛料のコーナがあり, やはり秤で量って売って
表 2 中国雲南のタイ族が用いている香辛料

\begin{tabular}{|c|c|c|c|}
\hline \multicolumn{2}{|c|}{ 中国名 } & （通䄳） & (植物科名) \\
\hline 生 & 姜 & ショウガ & ショウカ种 \\
\hline 辣 & 椒 & トウガラシ & ナス科 \\
\hline 香 & 菜 & コエンドロ & 七リ科 \\
\hline 薄 & 荷 & 八ッ力 & シソ科 \\
\hline 草 & 果 & ソウカ & ショウガ科 \\
\hline 花 & 椒 & サンショウ & ミカン科 \\
\hline 茴 & 香 & ウイキョウ & 七り科 \\
\hline 大 & 赫 & ニンニク & 二リ科 \\
\hline 八 & 角 & 八ッカク & シキミ科 \\
\hline 胡 & 椒 & コショウ & コショウ科 \\
\hline 代 & 代 & ダイダイ & ミカン科 \\
\hline 丁 & 香 & チョウジ & フトモモ科 \\
\hline 胡 & 麻 & $\exists マ$ & ゴマ科 \\
\hline
\end{tabular}

いて古新聞に包んで渡している。

夕イ族の農家は入母屋高床式の家屋であるが，その2 階の一角に炉を中心に台所がある。周囲に鍋, やかんが 抎か机, コ又袋や野菜がころがって少し雑然としている。 各戸に来ている水道と洗い場（水道は15年前に導入）が この台所に連って外 ( 2 階) につくられている. 日常の 食生活で, 普段料理としてつくる惣菜でもら一つ大事な ものに漬物がある、西双版納は南で暖いので訪れたとこ ろでは見かけなかったが，北部のタイ族の農家(この地 のタイ族はかなり漢民族の影響をらけ，漢化している） の一室に大小30個余りの瓶があって，これは何かとさい たところ，全部漬物の瓶だといら答でびっくりした、い つも新鮮な素材が手に入らないところは, こらして漬物 ら゙くが普及している。

\section{4.日本のイネ作とコメ食}

さて，不ハル，雲南をまわって日本のコ人食を考党 るとき, 何ょりも頡にらかぶのは, 日本はネパール, 雲 南よりずーっと北にあって，この北国まで南にあったイ ネをよくぞひっぱりあげたものだといら感慨である。

日本人はなぜュメを主食に選んだか問題になるが，私 はコメの味を知った民族が、ユ人をたずさえて日本列島 に渡来していったのではないかと考えている，その一つ の証拠に，耐寒性があり，アミロペクチンが多い粘りの あるジャポニカ米をわれわれは日常食べている. 現在, 最古のコメとして石に刻交孔た籾（岡山県総社の南溝手 遺跡) はこのジャポニカ型であった。

このイネ作を受け入れた日本の風土は, モンスーン地 帯に属し, 年間雨量平均 1,788 ミリと, ネパール, 雲南 に比べて最も多い，イネには何よりも水が大切である. 
その上，日本の土は火山灰の酸性黄褐色土で，酸性に強 いイネには適しているのである.

さて，この日本でも雲南やネパールと同じようにコメ を粒食のまま炊いて用いるご飯とそれに和する惣菜とい ら組合せが登場した。電気炊飯器の発明は日本人である が，その機構は蒸しこむジャポニカ米の粘りを出すのに 適している.ネパールでは鍋で炊いてふき出てくると蓋 をとり，扣さまるとまた蓋をするといった炊き方をして いた。

その惣菜の味つけをするものにどんなものを用いてい るか，表 3 に示してみよう。

表 3 日本で使われている香辛野菜

\begin{tabular}{|c|c|}
\hline 和 名 & 植物科名 \\
\hline ワサビ 和佐比 & (アブラナ科植物) \\
\hline ショウガ 生姜 & (ショウガ科) \\
\hline ミョウガ 若荷 & (ミョウガ科) \\
\hline サンショウ 山椒 & (ミカンン科) \\
\hline トウガラシ 唐辛子 & (ナス科) \\
\hline シソ 紫蘇 & (シソ科) \\
\hline ニンニク 化牟化久 & (ニリ科) \\
\hline ゴマ 胡麻 & (ゴマ科) \\
\hline ミッバ 三葉 & (セリ科) \\
\hline
\end{tabular}

この日本の香辛野菜の特徵をあげてみると, ネパール や雲南がセリ科などの種子一小さな粒状のものを多く用 いているが，日本では葉や根茎をすりつぶして生のもの を用いる，日本のものは成分としてはアリルカラシ油， シネオール， $\beta$-ピネン, リモネン, クリプトテーネン,

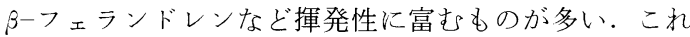
は生魚の生ぐさ味を消し，また素材そのものの味を殺さ ないよらに㗢くものを用いている。ネパールや雲南でト ウガラシのキャプサイシンなどは，その辛味の強烈さで 単調なご飯の味をひさたたせている。

これは国民性の気質に通ずるものを感じ，日本にはス パイス店がないこと，日本の台所のすり鉢は底が深くて 立派であることなど考えさせられる。

もら一つ，日本のコメ食の中で生み出された傑作は， すし（䰿, 鮨, 寿司) である.このすしもその起源は雲 南で，魚を貯蔵するのにコ人と塩を用いて保存したこと に端を発している。日本へは奈良時代の天平文化が盛え た頃渡来したが，これをくなれずし>，〈押ずし > $\rightarrow$ くちらしずし(五目ずし) $>$ として庶民の食生活に定着さ せていった歴史は素晴しいことである。〈江戸前ずし>
は文政年間（1820年）誕生したものであるが，握って固 めるのでジャポ二カ米の粘りがなくてはならない，その 固めたコメの上に薄切りにした新鮮な魚の刺身をのせる が，水がよくなくては駄目である。その魚のねたにつけ るワサビは清流で育って根茎に含まれているシニグリン が加水分解してッーンと鼻孔にくる揮発油の作用で，生 魚のくさ味を消してくれる，ワサビの利用など，日本人 ならではの発見のよらに思われる。ささらに脂肪分が多い マグロ (鮁) の切身が酢とコメの味にあって打いさを 一段と高めることから，すしの漢字を䰻から鮨に変えて いった経緯など，日本の食生活史に残るドラマのよらに 思与。

おわりに

このように照葉樹林帯に位置するネパール，雲南そし て日本の食生活のもとをみてみると，各民族が同じコメ 食を基礎に打きながらも，さまざまに多様化した食生活 の形態をとっていることに拈どろく．

ネパールではヒマラヤの自然と民族の歴史を背景にカ レー料理，それも民族によって香辛料の使い方を変えて， 単純な種類の素材から複雑な味をもつ料理を生み出して いる.

雲南ではコメ食の原点にたつ長い歴史をもちながら， コメそのものの素材を伝統的なものから近代化へ向けて 変換し，それに対応する惣菜とともに食生活の変容が進 行している.

日本は北国といら不利な条件の中で,イネ作を工夫し， コメ食を定着させ，風土に適った独自の食文化を発達さ せてきた。

こらした食生活の資料は，それぞれの民族がコ入食の 利点を活かし，居住する風土に適応して，どこまで豊か な食事ができるか，創意工夫から生まれた知恵の結集の 結果を物語っているよらに思われる.

\section{参考文献}

1） ベイカー, H. G. 著 阪本寧男・福田一郎訳：植物と文明, 東京大学出版会 (1975)

2）福田一郎·山本英治：コ入食の民族誌，中公新書 （1993）

3) Fukuda, I. et al: Scientific Research on the cultivation and utilization of major crops in Nepal (1983)

4）佐々木高明：雲南の照葉樹林のもとで，日本放送出版協会 (1984)

5）周達生：中国の食文化，創元社（1989）

6）渡辺実：日本食生活史，吉川弘文館（1964） 